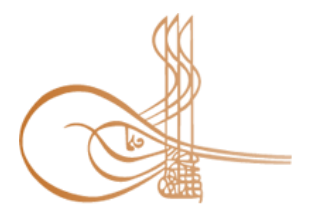

www.turkishstudies.net/history
Turkish Studies - Historical Analysis

eISSN: 2667-5552

Research Article / Araștırma Makalesi

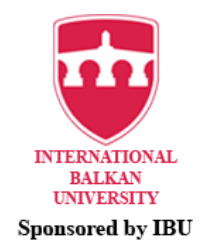

Sponsored by IBU

\title{
Türkiye Selçukluları Zamanında Kervansarayların Kale ve Savunma Yapısı Olarak Kullanılması"
}

\author{
Usage of Caravanserais as Fortress and Defense Structures During Turkey Seljuk State Era
}

\author{
Mehmet Suat Bal**
}

\begin{abstract}
In this study, the usage of caravanserais as fortress and defense structures during Turkey Seljuk State has been discussed. In the first part of the study, the events in which caravanserais were used as defense structures in political struggles were examined, as mentioned in the case of chronicles. In the second part, the structural similarities of caravanserais with fortresses were tried to be revealed. It has been understood that caravanserais were served as structures for accommodation, protection and as fortress and defense mechanism during Turkey Seljuk era. It has been observed that the use of caravanserais as defense structures increased after the Mongolian invasion. During the era of Turkey Seljuks, caravanserais were used as important defense structures as fortresses. The most important event related to this fact is that Alaiye Caravanserai could not be conquered despite being surrounded by 20 thousand Mongolian cavalry for two months. Although the siege was realized with the help of catapult, armor piercing arrows, it is a very important case that Alaiye Caravanserai did not fall and did not surrender to the enemy. Despite of such a large number of soldiers and siege weapons, the main reason why the mentioned caravanserai could not be taken was its thick and high walls. In addition, the large and wide internal volume of this building has provided an opportunity for accommodation of people and storage of food. Turkey Seljuk caravanserais; resemble to fortresses with their thick high walls like ramparts, crenel, buttresses and bastions, dentilled structures, stairs to the roof and big doors. Although it cannot be said that these monumental structures present a full fortress feature, it is certain that they are a full protection structure with their thick high walls. Caravanserais have been built bigger and more perfect during the rise of the Turkey Seljuk State.
\end{abstract}

Structured Abstract: In this study, the usage of caravanserais as fortress and defense structures during Turkey Seljuk State has been discussed. In the first part of the study, the events in which caravanserais were used as defense structures in political struggles were examined, as mentioned in the case of chronicles. In the second part, the structural similarities of caravanserais with fortresses were tried to be revealed. It has been understood that caravanserais were served as structures for accommodation, protection and as fortress and defense mechanism during Turkey Seljuk era. It has been observed that the use of caravanserais as defense structures increased after the Mongolian invasion.

\footnotetext{
* Bu makale Atatürk Kültür Merkezi Başkanlığının 27-29 Kasım 2015 tarihlerinde Sinop'ta düzenlediği "Selçuklu Kaleleri ve Savunma Yapıları" sempozyumunda sunulan "Türkiye Selçuklu Devleti Zamanında Kale ve Savunma Yapısı Olarak Kervansarayların Kullanılması" adlı bildirinin genişletilmesi ile oluşturulmuştur.

** Doç. Dr, Kahramanmaraş Sütçü İmam Üniversitesi, Fen Edebiyat Fakültesi, Tarih Bölümü

Associate Professor, KSU Faculty of Arts and Science, Department of History

ORCID 0000-0002-1426-9452

suatbal@hotmail.com

Cite as/ Atıf: Bal, M. S. (2020). Türkiye Selçukluları zamanında kervansarayların kale ve savunma yapısı olarak kullanılmas1. Turkish Studies - History, 15(3), 831-849. https://dx.doi.org/10.47846/TurkishStudies.45603

Received/Geliş: 06 August/Ağustos 2020

Accepted/Kabul: 20 September/Eylül 2020

Copyright (C) INTAC LTD, Turkey
} 
Turkey Seljuk State had made many studies for the revival of commercial life and had signed trade agreements. It was very important for caravans to travel safely to reap the benefits of these studies and agreements. If the safety of caravan roads was imperiled and the caravans were robbed, this was accepted as a direct reason for war. An example for this situation can be the following: The struggle between Iznik Laskaris and Trabzon Kommens on the Black Sea coast were disrupting public order and causing trade routes to be closed. İzzeddin II made sail to Sinop and conquered this city and brought peace and order to this region, so caused a significant harbor city to belong to Turkey Seljuks. As it is clearly seen in this case, caravanserais had to be extremely safe defense structures.

During the era of Turkey Seljuks, caravanserais were used as important defense structures as fortresses. The most important event related to this fact is that Alaiye Caravanserai could not be conquered despite being surrounded by 20 thousand Mongolian cavalry for two months. Although the siege was realized with the help of catapult, armor piercing arrows, it is a very important case that Alaiye Caravanserai did not fall and did not surrender to the enemy. Despite of such a large number of soldiers and siege weapons, the main reason why the mentioned caravanserai could not be taken was its thick and high walls. In addition, the large and wide internal volume of this building has provided an opportunity for accommodation of people and storage of food.

It is understood that Karamanoğulları encompassed Memres who was a Turkish lord, in Alaiye Caravanserai and it was a very tough siege. After this siege, two towers of the mentioned building were destroyed. After this caravanserai became unusable, the Konya-Aksaray road has become unsafe. In reality, the demolition of one of the towers or demolition of walls of a caravanserai does not prevent that caravanserai from being used for accommodation, but it remains defenseless. It is important to show that defense functions of caravanserais were prominent after the Alaiye Caravanserai whose two towers were destroyed became unusable and so the caravan road was closed. After the repair of Alaiye Caravanserai was completed, the trade route was secured and caravans started to come and go.

It is understood that although Turkey Seljuk era caravanserais did not bear a complete fortress identity with all associated elements, they did have a strong defense and protection properties. The structural similarity of the caravanserais with the fortresses has been examined within the framework of the following paragraphs:

-Thickness of caravanserai walls are in the range of 1.20-2.40 cm and are built of solid cut stone. It is possible to call the walls which are thick, high and supported by buttresses as rampart. Alaiye Caravanserai is one of the strongest caravanserais in Anatolia due to its relatively largest and strongest walls / ramparts compared to other caravanserais with its 13-meter-high crown gate and approximately 2-meter-thick walls. Other caravanserais, although not as high as Alaiye, are still high-walled structures. Considering the war technology of that period, the walls of 13 meters high and 2 meters thick were very difficult to overcome. For this reason, it can be said that caravanserais in Anatolia perform defense and security duties such as Alaiye Caravanserai.

- The walls of the caravanserais are drilled through small window openings, called the crenel which shrink from the inside out. Except for these spaces that meet the need for surveillance and light, there are no windows or spaces which are closed with shutters.

- It is observed that there is a parapet and dentil structure (trench, railing) between the buttresses on the roof of the caravanserais. It is understood that there is a parapet structure between $1.00 \mathrm{~cm}$ and $1.20 \mathrm{~cm}$ on the roof in Karatay Inn, Kayseri Sultanı Inn and Aksaray Sultan Inn. There are dentils on Alara Inn, Şarabsa Inn, Obruk Inn, and Kırkgöz Inn. Dentilled caravanserais with their strong appearances resemble fortresses. Dentils are also seen as a finish or an ornament on the roof of the building in Seljuk architecture.

- In order to use the roofs of the caravanserai for defense purposes, ascending to the roof should be easy with stairs. However, we come across stairs or stairwells on the roof of only 15 caravansaries.

- The doors of the caravanserais are strong, durable and of large scale which are made of the best iron. Entry and exit is made through a single door to caravansaries.

Turkey Seljuk era caravanserai structures are similar inn used in the Turk Islam states. These inn were primarily made as outpost but later they served to lodge, Islamic monastery, madrasah and commercial caravans for accommodation and protection. We understand that Turkey Seljuk Era caravanserais were also

Turkish Studies - History, 15(3) 
used for such multi purposes. Of course, this situation was shaped according to the needs of the period. The purpose of the construction of these caravanserais was to provide protection and accommodation services to commercial caravans at the beginning. However, with the change of time and conditions, these buildings were used as military bases during domestic and foreign struggles, accommodation places of the rulers, outpost, fortresses for defense purposes and prisons.

Turkey Seljuk caravanserais; resemble to fortresses with their thick high walls like ramparts, crenel, buttresses and bastions, dentilled structures, stairs to the roof and big doors. Although it cannot be said that these monumental structures present a full fortress feature, it is certain that they are a full protection structure with their thick high walls. Caravanserais have been built bigger and more perfect during the rise of the Turkey Seljuk State.

Keywords: Turkey Seljuk State, Caravansaries, Fortress and Defenses, Mongols.

Öz: Bu çalışmada Türkiye Selçuklu Devleti zamanında kervansarayların kale ve savunma yapısı olarak kullanılışı ele alınmışııı. Çalışmanın ilk kısmında vakayinamelerde geçen şekliyle kervansarayların siyasi mücadelelerde savunma yapısı olarak kullanıldığı olaylar incelenmiştir. İkinci kısımda ise kervansarayların kalelerle olan yapısal benzerlikleri ortaya konmaya çalışılmıştır. Türkiye Selçuklu devri kervansaraylarının konaklama, koruma, kale ve savunma yapısı olarak hizmet etmiş yapılar olduğu anlaşılmıştır. Kervansarayların savunma yapısı olarak kullanılmasının Moğol istilasından sonra arttığı görülmüştür. Türkiye Selçukluları zamanında Kervansarayların kale gibi önemli bir savunma yapısı olarak kullanılmıştır. Bununla ilgili en önemli olay Alaiye Kervansarayı'nın iki ay boyunca 20 bin Moğol süvarisi tarafindan kuşatılmasına rağmen alınamamasıdır. Kuşatmanın manıınılar ve zırh delen oklar yardımıyla yapılmasına rağmen Alaiye Kervansarayı'nın düşmemesi ve düşmana teslim olmaması çok mühim bir hadisedir. Bu denli fazla sayıda asker ve kuşatma silahına rağmen adı geçen kervansarayın alınamamasının en önemli sebebi kalın ve yüksek duvarlara sahip olmasıdır. Ayrıca bu yapının geniş ve büyük iç hacmi insanların barınması ve yiyecek depolamaları için fırsat tanımıştır. Türkiye Selçuklu kervansarayları; sur gibi kalın yüksek duvarları, mazgalları, payanda ve burçları, dendanlı yapıları, çatıya çıkan merdivenleri ve büyük kapıları ile kalelere benzemektedir. Bu abidevi eserlerin tam bir kale özelliği gösterdiği söylenemezse de kalın yüksek duvarları ile tam bir korunma yapısı olduğu kesindir. Kervansaraylar Türkiye Selçuklu Devleti’nin yükseliş devrinde daha mükemmel ve daha büyük hale getirilmiştir.

Anahtar Kelimeler: Türkiye Selçuklu Devleti, Kervansaraylar, Kale ve Savunmaları, Moğollar.

\section{Giriş}

Türkiye Selçuklu Devleti, Türk Devlet geleneğini, kültür ve sanat mirasını Anadolu'ya taşımış ve yaşatarak zenginleştirmiştir. Büyük Selçukluların bir kolu olarak Anadolu'ya gelen Türkiye Selçuklu Devleti, siyasi açıdan güçlü, ekonomik yönden zengin bir devlet olmuştur. Bu zenginlik beraberinde muhteşem mimari eserlerin doğmasına zemin hazırlamıştır.

Türkiye Selçuklularının mimari anlayışı, Türk sanatı ve Anadolu'ya yansıyan insanlığın ortak mirasının birleşimiyle ortaya çıkmıştır. Türkiye Selçukluları, Büyük Selçuklularda olduğu gibi, devlet diplomasisinde İranlıların, din işlerinde de ise Arapların tesiri altında kalmışlardı. Türkiye Selçukluları, mimari konularda ise yeni yurt edindikleri, Anadolu ve çevresindeki mimari bilgi birikiminden faydalanmışlardı. Konut, kale, su yapıları ve sur gibi mimari eserlerin yapımı yerli Hristiyan ustalara ve onların işgücüne dayanıyordu. Bunun yanında mimarinin gelişmesi için farklı uzmanlık konularında çevre ülkelerdeki ustalardan faydalanmışlardı. Kuban (2002:71-72)bu durumu şu cümlelerle ifade eder:

"Bir mukarnas ustası Suriye'den, bir tuğla ustası Azerbaycan'dan, bir hattat Musul'dan, bir taş oymacı Gürcistan'dan yada Cezire'den gelmiş olabilirdi. Bunların yan yana gelmeleri, değişik yörelerin biçim ve tekniklerinin ortaya konması, şantiyedeki ustalar tarafından önce bir zanaatkârlık göstergesi olarak, sonra estetik bir olgu olarak değerlendirilmesi ve bütün bu süreçlerin, binlerce kez her seferinde değişik 
varyasyonlarla mimari üretim olgusuna katılması Selçuklu mimarisi ve sanatı denen fenomeni doğurmuştur."

Türkiye Selçuklularının mimari anlayışının bu gelişim sürecini bilmeden ilerde bahsedilecek olan mükemmel sevideki mimari yapıların nasıl ortaya çıktı̆̆ını anlamak mümkün olmayacaktır.

Kervansaraylar tacirlerin konaklaması ve ihtiyaçlarının karşılanması için inşa edilen yapılardır (Bkz. Erdman, 1961; Turan, 1946; Özergin, 1956; Sönmez, 1989; Aslanapa, 1989; Aslanapa, 1991). Kervansaray kelimesi yerine kaynaklarda yer yer ribât ve han tabirleri de kullanılmıştır. Ticaret yolları üzerinde birer günlük konaklama mesafesinde kurulan kervansaraylar tacirlerin güvenliğini de sağlıyordu. Çok değerli emtia taşıyan kervanlar için güvenlik diğer ihtiyaçlardan da önemli idi. Şehir merkezlerinden uzak yollarda özellikle geceleri kervanları bekleyen eşkıya tehlikesi bulunmaktaydı. Bu sebepten kervansarayların içi tacirlerin ihtiyaçlarını karşılamak için inşa edilirken, güçlü dış duvarları da değerli eşya taşıyan kervanları koruma amaçlı olarak yapılmıştı.

Kervansarayların güçlü dış duvarları/surları sayesinde korunaklı bir kale olarak da kullanıldığı görülmektedir. Gerek Anadolu'nun konumu gerekse Türkiye Selçuklu Devleti'nin hareketli siyasi yapısından dolayı Anadolu'da meydana gelen savaşlar ve mücadelelerde kervansarayların sığınma ve savunma işleviyle birlikte bölge güvenliğinin sağlanmasına da yardımcı olduğu görülmektedir.

Türkiye Selçuklu Devleti, ticari hayatın canlanması için birçok çalışma yapmış ve ticaret anlaşmaları imzalamıştı. Bu çalışma ve anlaşmaların meyvesini almak için kervanların güvenli seyahat etmesi büyük önem taşımaktaydı. Zira kervan yollarının güvenliğinin tehlikeye girmesi ve kervanların soyulması direkt olarak savaş sebebi sayılıyordu. Bu duruma örnek olarak şu olay gösterilebilir: Karadeniz sahilinde İznik Laskarisleri ile Trabzon Kommenleri arasındaki mücadele asayişi bozuyor, ticaret yollarını kapatıyordu. II. İzzeddin Sinop üstüne sefere çıkarak bölgede asayiş ve düzeni sağlamış Sinop'u alarak önemli bir liman kentini Türkiye Selçuklularına kazandırmıştır (Bal, 1998: 14). Bu olayda da açıkça görüldüğü üzere kervansarayların son derece güvenli savunma yapıları olması gerekmekteydi.

Türkiye Selçuklu Devletinin en önemli şehirlerinin bulunduğu iç Anadolu bölgesi aynı zamanda ticaret yollarının da ana arterlerini oluşturmaktaydı (Harita 1-2). Bu sebeple en fazla sayıda kervansaray Konya-Kayseri-Sivas güzergâhında bulunmaktaydı. Ana arterlerin korunma ihtiyacı daha fazla olduğu içinde en güçlü savunma yapısı olan kervansaraylar yine bu bölgedeydi (Özcan, 2015: 189)

\section{Kervansarayların Kale, Savunma ve Emniyet Yapısı Olarak Kullanılması}

Türkiye Selçukluları devri vakayinamelerinde geçen olaylar incelenmiş ve kervansarayların fonksiyonları aşağıdaki kısımlarda ayrı ayrı değerlendirilmiştir.

\section{1. Hapishane Olarak Kullanılması}

II. Gıyâseddin Keyhüsrev'in 1246 yılında ölümünden sonra kardeşler arasında yaşanan taht kavgaları sırasında kervansarayların savunma yapısı olarak kullanıldığı görülmüştür. Sultan II. İzzeddin Keykavus ve Sultan Rükneddin Kılıç Arslan 1249 yılında Alaiye Kervansarayı (Sultan Hanı) (Fotoğraf 6,7) önünde savaşmışlardır. II. İzzeddin Keykâvus bu savaştan başarıyla çıkmış ancak kardeşini bağışlamayı bilmiştir. Bu savaştan sonra iki kardeşin arasını bozan ihtiraslı emîrler cezalandırılmıştır. Tutuklanan emîrler Alaiye Kervansarayı'na hapsedilmiştir (İbn Bibi, 1996: 124; Turan, 2013: 487). Bu durum kervansarayların hapishane olarak kullanıldığını göstermektedir. Bu olaydan sonra Konya'ya doğru hareket eden İzzeddin Keykavus'u karşılamak isteyen coşkulu halk, Sadeddin Köpek Kervansarayı'na kadar gelmiş karşılama merasimini orada yapmıştır. 


\section{2. Sinır Kalesi ve Karakolu Olarak Kullanılması}

Kervansaraylar askeri mücadelelerde kale ve sınır karakolu görevi de görmekteydi. $\mathrm{Bu}$ konuda şu örnek olay dikkate değerdir: Sultan II. İzzeddin Keykâvus ile IV. Rükneddin Kılıç Arslan arasında Kayseri ve Kırşehir hâkimiyeti paylaşılamıyor, bu olay anlaşmanın pürüz noktasını oluşturuyordu. Sultan Rükneddin'in emîrleri Alaiye Kervansarayı'na kadar olan bölgeyi ellerinde tutmaktaydılar. Felekeddin Halil ile Hüsameddin Baycar askerleri ile Alaiye Kervansarayı'na kadar gelmiş ve burasını yağmalamışlardı. Bu sebepten, Aksaray-Kayseri yolu güvenli değildi (İbn Bibi, 1996: 140) Bu olaydan da anlaşılacağı üzere Alaiye Kervansarayı iki ordu arasında bir sınır kalesi görevi görmekteydi.

\section{3. Savaş Öncesi Askeri Üs ve Kale Olarak Kullanılması}

Sultan II. İzzeddin Keykâvus Moğolların Anadolu'daki hâkimiyetlerini bitirmek için Türkiye Selçuklu Devleti'nin son savaşını vermiştir. Sultan Hanı savaşı (1256) Sultan II. İzzeddin Keykavus ile Baycu komutasındaki Moğol ordusu arasında Alaiye Kervansarayı düzlügünde yapılmıştır (İbn Bibi bu kervansaraydan "Kervansarayi Sultan Alaeddin" şeklinde bahsederken Aksarayî ise "Ribât-1 Alayi" şeklinde bahsetmektedir. Anonim Selçuknâme ve el-Veled el-Şefîk, ismi geçen hanı "Sultan Alâeddin Kervansarayı" olarak anlatır. İbn Bibi 1946: 146; Aksarayî, 2000: 32; Anonim Selçuknâme, 1952. 33; Kadı Ahmed, ty. 297). Bu büyük ve önemli savaş öncesi, II. İzzeddin Keykavus'un askerleri adı geçen kervansaraya gelerek burayı bir savaş üssü olarak kullanmıştır (İbn Bibi, 1996: 146; Bal, 2004: 98-103). Bu olay kervansarayların savaş öncesi bir üs olarak kullanıldığını göstermektedir. Konya-Kayseri-Sivas gibi önemli şehirlerin güzergâhında sıklıkla yer alan büyük ve gösterişli kervansaraylar, hükümdarların bu menzilleri sıklıkla kullanmalarıyla da ilişkilidir (Yavuz, 1992: 253).

II. İzzeddin Keykâvus'un Antalya'dan İstanbul'a kaçmasından (1262) sonra Karaman, Zeynü'l-Hac, Bunsuz, Ali Bahadır ve Emîr-i Âhur Uğurlu, topladıkları 20.000 kişilik bir ordu ile Altunaba Kervansarayı'na gelmişlerdi. Bu emîrler Moğol ordusunun yaylalara dağılmasından faydalanarak, Sultan IV. Rükneddin Kılıç Arslan'1 devirmek amacıyla, Konya'yı kuşatmayı planlıyorlard1. Pervâne Muîneddin, hemen toparlanan Moğol askerlerinin de desteği ile bu emîrlerin isyanını bastırdı. Ali Bahadır ve Emîr-i Âhur Uğurlu uç bölgelerine geri kaçtılar (Bal, 2005: 5). Bu olayda da Altunaba Kervansarayı'nın bir üs ve kale olarak kullanıldığını görmekteyiz.

Türkiye Selçuklu Devleti’nin Moğol istilası ve iç karışıklıkları ile mücadele ettiği 1277 yılında Hatiroğlu İsyanı, Karamanoğlu Mehmet Bey İsyanı ve Baybars'ın Anadolu'ya gelmesi gibi önemli olaylar yaşanmıştı. Bu olayların hemen ardından Kızıl Hamid isminde bir iltizam sahibi Aksaray'ın vergilerini İlhanlılar adına topluyordu. Kızıl Hamid ülkenin içinde bulunduğu siyasi karışıklıklardan faydalanarak halka zulümler yapıp fazla miktarda vergi almaya başlamıştı. Kızıl Hamid 4000 kişilik bir süvari kuvveti ile Aksaray'a hâkim olmuştu. Tam bu dönemde Moğol askerlerinin geldiği ve Hoca Me'sud (Ağzıkara) Kervansarayı'nda (Fotoğraf 5) bir Moğol karakolu oluşturdukları haberi duyuldu. Moğollar tarafından yağmalanan birkaç kişi onların geldiğini haber verdiyse de Kızıl Hamid onlara inanmadı. Kızıl Hamid'in vergilerini toplayan Şengiti Aksarayî, Hoca Me'sud Kervansarayı'na gelen askerlerin Moğollar değil onların bir Türk emîri olan Emirüssayd Garsüddin'in topladığı askerler olduğunu belirtti. Onların Kızıl Hamid'i ortadan kaldırmak için Moğol kisvesi altında Eyüp Hisar ve Saleme'den gelen askerler olduğu anlaşıldı. Moğolların geldiği şeklinde yanlış haberler veren kişiler ağır şekilde dövülerek cezalandırıldı. Bu olaydan sonra Kızıl Hamid, Aksaray'da büyük yağma yapmıştır. Kızıl Hamid, Hoca Me'sud Kervansarayı'na gelen Emirüs-sayd Garsüddin'in askerlerinden büyük korkuya kapılıp onları bütün gücüyle takibe koyulmuştur (Aksarayî, 1996: 97-98; Turan, 2013: 580).

Yukarıdaki olaylara bakıldığında Moğolların Aksaray yakınlarına gelerek büyük ve muhkem bir mevzi olan Hoca Me'sud Kervansarayı'nı ele geçirmeleri Kızıl Hamid'i endişeye düşürmüştür. Her ne kadar bu kervansaraya gelen askerlerin Emirüs-sayd Garsüddin'in toplamış 
olduğu askerler olduğu sonradan anlaşılsa da bu mevziinin ele geçirilmiş olması haberi Kızıl Hamid'i büyük korkuya sevk etmiştir. $\mathrm{O}$, bütün adamları ile onlara karşı mücadele hazırlığına girişmiştir. Bu olay Hoca Mesud Kervansarayı'nın ne kadar önemli bir kale konumunda olduğunu göstermesi bakımından kayda değerdir.

Kızıl Hamid askerleri ile bölgeye hâkim olduğu dönemde Şehzade Kongurtay, Eyüp Hisar'a ulaşmış ve Pervane Kervansarayı'nda konaklamıştı. Kongurtay, Pervane Kervansarayı'nda konakladıktan sonra ordusuyla Aksaray'a yürümüş ve Kızıl Hamid'i öldürerek halkı (6000 kişi) k1lıçtan geçirip esir etmiştir (Aksarayî, 1996: 98; Turan, 2013: 581). Görüldüğü gibi Şehzade Kongurtay, Pervane Kervansarayı'nı bir askeri üs olarak kullandıktan sonra Aksaray'1 istila etmiş̧tir.

\section{4. İç Mücadelelerde Korunaklı Sığınma Yeri Olarak Kullanılması}

Baybars'ın Kayseri'ye gelmesinden sonra III. Giyâseddin Keyhüsrev, Pervane ve diğer devlet adamları ile birlikte Tokat'a çekilmiştir. Bu olayı takiben Karamanlılar, Konya'yı kuşatmış ve kapılarını yakıp yıkarak şehre girmeye çalışmışlardır. Eminüddin Mikail şehrin düşeceğini anlayınca kıyafet değiştirerek, Tokat'a kaçmak için yola çıkmıştır. Eminüddin Mikail yolda Kaymaz Kervansarayı'na sığınmıştır. Burada korkusuz Türkler ve Ermenek haydutlarından beş altı kişi Eminüddin Mikail'i yakalayarak Karamanoğlu Mehmet Bey'in yanına götürmüşlerdir. Karamanoğullarının en şiddetli düşmanlarından olan Eminüddin Mikail sakladığı mallarının ve eşyalarının ele geçirilmesinden sonra öldürülmüş̧ür. Karamanoğulları 1277 de hızlıca Konya şehrine girmişlerdir (İbn Bibi, 1996: 206; Turan, 2013: 578).

Eminüddin Mikail'in Karamanoğulları'nın baskısı karşısında kendini korumak için Kaymaz Kervansarayı'na sığınması, bu yapının korunaklı bir yer olduğunu ve iç mücadelelerde bir sığınma yeri olarak da kullanıldığını göstermektedir

\section{5. Savunma ve Emniyet Yapısı Olarak Kullanılması}

Kervansarayların kale gibi önemli bir savunma yapısı olarak kullanılmıştır. Bununla ilgili en önemli olay Alaiye Kervansarayı'nın iki ay boyunca 20 bin Moğol süvarisi tarafından kuşatılmasına rağmen alınamamasıdır. Bu hadiseyi Aksarayî detaylı bir şekilde şöyle anlatmaktadır:

“Bu zamanda İrencin Rum'a gelip ülkeyi dolaştı. Konya tarafina hareket edince Türk emirleri İlyas adındaki bir büyük Alaiye Hanına gelmişti. Oraya sığınarak ayaklandı. Huzura gelmedi. (İrencin) Türk ve Tacik ordusunu onu kuşatmakla görevlendirdi. Onlar 2 ay müddetle 20 bin kadar süvariyle gece ve gündüz vakitlerini oranın fetih işine harcadılar. Fakat ne taş yağdıran mancınıkla zafer kazandılar ne de zırhı delen okla hâkimiyet kurdular. Ne ateş atan arrade ne de dünyayı yakan şimşeğe benzeyen neffâte işe yaradı. Ondan sonra kim bir bölgede bir kervansaraya veya bir şehirde bir hastahaneye (dârü'ş-şifâ) sı̆̆ındıysa, taşkınlığa başladı. Bunlara o hanın (ribât) kuşatması örnek oldu. O (handaki) fitnenin maddesi, asilerin düşmanlıklarının yayılmasına sebep oldu." (Aksarayî, 1996; 242).

Ana kaynağın verdiği detaylara bakıldığında 20.000 kadar süvarinin iki ay müddetince kuşattığı bir yapıyı ele geçirememesi önemli bir olaydır. Kuşatmanın mancınık, zırh delen oklar, ateş atan arrade ve neffate yardımıyla yapılmasına rağmen Alaiye Kervansarayı'nın düşmemesi ve düşmana teslim olmaması çok mühim bir hadisedir. Bu denli fazla sayıda asker ve kuşatma silahına rağmen adı geçen kervansarayın alınamamasının en önemli sebebi kalın ve yüksek duvarlara sahip olmasıdır. Ayrıca bu yapının geniş ve büyük iç hacmi insanların barınması ve yiyecek depolamaları için firsat tanımıştır.

$\mathrm{Bu}$ kuşatmadan sonra İrencin'in, Müsameretü’l Ahbar'ın yazarı olan Aksarayî̀ye verdirdiği bir ceza bize Alaiye Kervansarayı'nın ne kadar önemli bir savunma yapısı olduğunu gösteren diğer delildir. Kaynağın verdiği bilgiler şöyledir: 
“İlk olay Alaiye Hanı olayıydı. Bu konuda yazar şöyle diyor; 'o yıl cihan padişahı Gazan'ın yarlıg hükmüne göre ülke vakıfların yönetimine (tevliyet-i evkaf-ı memalik) sahiptim. Karamanlılar, büyük sultan Alaiye Hanına -Allah orayı kuranların yüzünü ağartsın- gelen ve hayırlı yere sığınan itibarlı Türklerden Memreş'e olan düşmanlıkları dolayısıyla o hanın burçlarından ikisini yıkmışlar, o yakım dolayısıyla Konya-Aksaray yolu tamamen kapanmıştı. Ülke vezirlerinin yarlıg ve altın damga hükmüyle kendi özel hazinemden (hassa) karşılığı vakıflardan sağlanır ümidiyle 10 bin dirhemi (aded) o burçların yapımı için harcadım. İki yıl sonra o handa yeniden canlanma oldu. Halka güven geldi, yollar açıldı." (Aksarayî, 1996: 246-247).

Aksarayî’ye bakıldığında Karamanoğullarının bir Türk beyi olan Memreş’i Alaiye Kervansarayı'nda kuşattığ 1 ve bu kuşatmanın çok çetin geçtiği anlaşılmaktadır. Bu kuşatmadan sonra adı geçen yapının iki burcu yıkılmıştır. Bu kervansarayın kullanılamaz hale gelmesinden sonra Konya-Aksaray yolu güvensiz duruma düşmüştür. Aslında bir kervansarayın burçlarının veya duvarlarından birinin yıkılması o kervansarayın konaklama için kullanılmasına engel değildir ancak savunmasız kalmasına neden olmaktadır. İki burcu yıkılan Alaiye Kervansarayı'nın kullanılamaz hale gelmesi ve kervan yolunun kapanması, kervansarayların savunma işlevlerinin daha ön planda olduğunu göstermesi bakımından önemlidir.

Alaiye Kervansarayı'nın onarılmasından sonra ticaret yolunun güvenliği sağlanmış ve kervanlar gelip gitmeye başlamıştır. Ancak ticaret yolunun normale dönmesi iki yıl gibi uzun bir sürede gerçekleşmiştir. Bu olay insanların güvenli bir kervansaray olmadan ticarete kalkışma konusunda ne kadar büyük bir çekince içinde olduklarını ortaya koymaktadır.

Aksarayî’nin verdiği bilgilere göre Memreş 50 adamıyla Alaiye Kervansarayı'ndan kaçtıktan sonra Eyüphisar Kalesi'ne sığınmıştır. Bu olayda aslında Alaiye Kervansarayı'nın sığınılacak bir yer olarak kalelere benzediğini gösterir (Aksarayî, 1996: 248-249).

Alaiye Kervansarayı'nın imar edilmesinin ardından meydana gelen başka bir olay Aksarayî tarafından şöyle anlatır:

“Türk emirlerinden İlyas adındaki biri o hana geldi ve İrencin'e başkaldırdı. Bundan önce anlatıldığı gibi İrencin, 20 bin adamla iki ayı orayı kuşatmakla geçirdiyse de oranın alımında kusurlu kaldı. Daima soysuz varlığı yıkıma sebep olan, vilayetlerin imarı, soysuz kavminin mezhebinde büyük bir suç sayılan Şenğit-i Aksarayî oğlu'nun dedikodusuyla İrencin ben zavallıya, İslam'ın şartlarının gerektirdiği imar işini yapma suçunu yükleyerek azarlarda ve yergilerde bulundu. Yani bu han, imar edilmiş duruma getirilmeseydi, İlyas oraya sığınmazdı, diye düşündü. $\mathrm{O}$ desteksiz bahaneyle $\mathrm{o}$ kuşatmada öldürülmüş olan her Moğol'un kan bedelini (hun-behâ) bu zayıfa yükledi. Hayır kurumu için harcadığım 10 bin dirhem (adet) masrafa ek olarak Moğol maktullerin cezası olarak zorla aldılar. 6 bin dirhem zararı da yüklendim. Velhasıl İslam'da ve yönetim şartlarında ülke vakıflarının yöneticisi, yıkım suçuyla suçlanabilir. Halbuki İrencin yönetiminde ceza ve suç, imar suçlamasıyla verildi. Bu ters hüküm zamanın ender durumlarından biridir.” (Aksarayî, 1996: 246-247)

Görüldüğ̈̈ gibi İrencin, Alaiye Kervansarayı'nın iki ay boyunca kuşatılıp alınamamasının sebebini duvarların ve burçların onarılmış olması ile açıklamaktadır. Bu onarımı yapan Aksarayî de yıkım suçuyla değil de yapım suçuyla ceza almasını şaşkınla ifade etmektedir. Bu olaydan herhangi bir yapı eksikliği olmayan kervansarayların kale gibi kuvvetli olduğu anlaşılmaktadır.

Moğolların Anadolu'da hâkimiyetlerine engel olacak hiçbir yapı istemedikleri bahsi geçen olaylardan anlaşılmaktadır. Zira asiler Moğollara karşı kervansaraylara sığınarak kendilerini korumaya çalışmışlardır. Kervansarayların güçlü duvarlarını aşamayan Moğollar bunları onaranlara da kızgınlıklarını göstermiş̧lerdir. Nitekim O. Turan kervansarayların yanında darüşşifaların da emniyet ve müdafaa bakımından mühim eserler olduklarını belirtmekte ve bu olayla ilgili olarak: "Müstahkem ve muhteşem kervansarayların ve darüşşifaların emniyet ve müdafaa bakımından da ne derece mühim olduğunu ve asilerin neden bu binalara sığındıklarını" ifade etmektedir (Turan, 
2013: 650). Bu sebepten Anadolu'da Moğollar, doğuda istila ettikleri ülkelerdeki kadar yıkıcı olmasalar da yine de kendilerine karşı kullanılır endişesi ile kale ve kervansaraylardan bazılarını yıkmışlardır (Bal, 2004: 261).

\section{Kervansaraylarla Kaleler Arasındaki Yapısal Benzerlikler}

Kervansaraylar, Türk İslam dünyasında ribâtların devamı mahiyetinde yapılar olup devrin kaynaklarında ribât ve han (Bal, 1998: 23-43) kelimeleriyle aynı anlamda kullanılmaktadır (Turan, 1946: 489). Han kelimesi özellikle şehir merkezlerinde tacirlerin konakladığı ve mallarını depolayıp pazarladıkları mekân anlamında kullanılır. Genel olarak kervansaraylara da han denilir. Ancak şehir merkezindeki kervansaraylara han denilmez. Yani bu iki kelime direkt olarak birbirinin karşılığı sayılmaz. Ribâtlar Türk-İslam dünyasında sınır boylarında ve stratejik yerlerde askeri amaçlı müstahkem yapılar olarak tanımlanır. Bu yapılar İran ve Maveraünnehr bölgelerinde IX. yy civarında askeri karakterini kaybedip tekke ve zaviye şeklinde de kullanılmaya başlanmıştır. Ticaret yolları üzerinde inşa edilen ribâtların da yol güvenliği ve konaklama ihtiyaçları için kullanıldığı görülmektedir. Bunun ilk örneklerinden biri Gazneli Mahmud'un emri ile Serahs yolu üzerinde Meşhed yakınlarında yaptırılan Ribât-1 Mâhî/Ribât-1 Çâhe'dir (Yiğit, 2008: 76-79). Türk İslam devletlerinde ticaret yolları üzerinde ve sınır boylarında inşa edilen bu yapıların devrin ihtiyaçlarına göre kale, karakol, tekke, zaviye ve kervansaray olarak farklı amaçlar için kullanıldığ görülmektedir (Turan, 1946: 489). Ribâtlar, zaman içinde etrafına evlerin yapılması ile bulundukları bölgeyi yerleşim merkezi haline getirmişlerdir. F. Köprülü (1942: 267-278)'ye göre; Türkiye Selçuklu Devleti'nde de kervansarayların kale ve savunma yapısı olarak kullanılması, ribât geleneğinin ve devrin ihtiyaçlarının bir sonucu olarak değerlendirilir.

Kervansarayların savunma yapısı ve kale olarak kullanılmasına dair vakayinamelerde anlatılan olayların yanında bu yapıların mimari özelliklerinin de incelenmesi gerekmektedir. $\mathrm{Bu}$ abidevî eserlerin mimari özelliklerini ve kalelerle/savunma yapıları ile benzerliklerini A. T. Yavuz farklı boyutları ile ele almıştır (Yavuz, 1992: 253-282). Onun değerlendirmesine bakılarak kervansarayların kalelerle yapısal benzerliği aşağıdaki ana başlıklar çerçevesinde incelenmiştir.

\section{1. Sur-Duvar}

Kervansaray duvarları kalınlığ $1.20-2.40 \mathrm{~cm}$ aralığındadır ve sağlam kesme taştan inşa edilmiştir. Payandalarla desteklenmiş kalın sağlam ve yüksek duvarlara sur demek mümkündür (Yavuz, 1992: 255). Alaiye Kervansaray1 13 metre yüksekliğindeki taç kapısı ve yaklaşık 2 metre kalınlığındaki duvarları ile Anadolu'daki kervansaraylar içerisinde en büyük ve güçlü surlara/duvarlara sahip kervansaraylardan biridir (Kuban, 2002: 242). Diğer kervansaraylar bu kadar yüksek olmasa da yine de yüksek duvarlı yapılardır (Güler, 2019:2307). O günün savaş teknolojisi düşünüldüğünde 13 metre yüksekliğinde ve 2 metre kalınlığındaki duvarların aşılması çok zordu. Bu sebepten Anadolu'daki kervansarayların Alaiye Kervansaray1 gibi savunma ve güvenlik görevlerini yerine getirdiği söylenebilir.

\section{2. Mazgal-Pencere}

Kervansarayların duvarları içten dışa daralan, mazgal adı ile anılan, küçük boyutlu pencere açıklıkları ile delinmiştir (Fotoğraf 14). Şarapsa Han'ın dört duvarında bulunan mazgallar bu konuda dikkat çekici örneklerdendir (Fotoğraf 8). Gözetleme ve 1şık ihtiyacını karşılayan bu aralıklar haricinde pencere veya kepenkle kapatılan bir aralık bulunmamaktadır (Yavuz, 1992: 255). Ağzıkara Han ve Alara Han'ın üst katında iç duvarla dış duvar arasında bir hücre bulunur. Ağzıkara Han'da bu hücre, hanın önüne açılan düzlüğü görecek şekildedir. Kervansaraylarda dışarı ile bağlantı sadece tek ve büyük ölçekli ana giriş kapısıdır.

\section{3. Burç-Payanda}

Kervansarayların duvarları payandalarla desteklenmiştir. Payandaların sayısı ve boyutu kervansarayların büyüklüğü ile doğru orantılı olup iki ile yirmi dört arasında değişmektedir. 
Payandaların şekilleri çok türlüdür ve özellikle ön cephelerde yıldız dilimli ve kabarık örgülü şekilde gösterişli burç formunda yapılmışlardır. Ancak payandalara burç veya kule demek her zaman mümkün değildir. Zira burç veya kulelerin çatıdan yüksekliği ve bu yapılar arasında uzanan dendanlı (diş diş çıkıntıları olan duvar) yapılar onların koruyucu yapı özelliklerini belirler (Yavuz, 1992: 257). Bunun yanında Selçuklu mimarisinde payandalı yapıların cami medrese ve türbelerde de kullanıldığı görülmektedir.

\section{4. Dendanlı Yapı}

Kervansaray duvarlarının tam bir sur yapısında olması için dendanlı bir yapı veya çatı üstünde payandalar arasında parapet (siper, korkuluk) yapı olması gerekmektedir. Karatay Hanı (Fotoğraf 2,3), Kayseri Sultanı Hanı ve Aksaray Sultan Hanı'nda çatı üstünde $1.00 \mathrm{~cm}$ ile $1.20 \mathrm{~cm}$ arasında parapet yapının (Fotoğraf 4,5,6) olduğu görülür (Yavuz, 1992: 257). Bu yapılarda mazgal veya dendan olmadığı için yüksek olsalar bile dışarıya nişan almak veya gözlem yapmak mümkün değildir (örnek kale ve dendan yapısı için bakınız: Fotoğraf 1). Alara Han (Fotoğraf 10) Şarabsa Han (Fotoğraf 8) Obruk Han (Fotoğraf 11, 12) ve Kırkgöz Han (Fotoğraf 13) üzerinde dendanlar mevcuttur. R. M. Riefstahl Şarabsa Hanı "Görünüşü heybetlidir. Karşıdan bir kale manzarası arz eder. Ağır ve pek muntazam olmayan taşlardan inşa edilmiştir. Dört köşesinde penceresiz dört tane kule ve iki cenahında dokuz tane çıkıntı vardır. Bu çıkıntılar dahildeki inşaatın zayıf olan kısımlarına destek teşkil etmektedir. Duvardaki mazgallar hana daha muzlim bir manzara verir" (Riefstahl, 1941: 51) biçiminde tasvir etmektedir. Denizden tarafından bu yapıyı görenlerin kaleden başka bir yapı olduğunu düşünmesi pek mümkün değildir.

R. M. Riefstahl, Şarabsa Han'ın doğusunda bir gözcü kulesinin bulunduğunu bu kulenin denizi gözlemek veya işaret vermek için yapılmış olabileceğini belirtir (Riefstahl,1941:50-51). Ancak alan araştırmasında bu yapının ana binanın üçte biri yüksekliğinde olması dolayısı ile kule hüviyetinden çok nöbetçi binası özelliği gösterdiği düşünülmektedir (Bal, 2020; Fotoğraf 8).

Dendanlı kervansaraylar güçlü görüntüleri ile kaleleri andırmaktadır (Bakkal, 2019: 549). Bunun yanında dendanlar, Selçuklu mimarisinde yapının çatı kısmında bir bitiş veya bir süs olarak da görülmektedir. Konya'da Gömeç Hatun Türbesi bu tür dendanlı yapılara örnek olarak gösterilebilir (Fotoğraf 15). Bazı kervansarayların dendanlı ve parapetli yapıları ile şekil olarak kalelere benzediği düşünülse bile işlevsel olarak dendan ve parapetlerin kullanışlı olmadığı anlaşılmaktadır.

\section{5. Merdiven}

Kervansarayların çatılarının savunma amaçlı kullanılabilmesi için çatıya çıkışın kolay olmas1 gerekmektedir. Ancak sadece 15 kervansarayın çatısına çıkan merdiven veya merdiven kalıntısına rastlamaktayız (Yavuz, 1992: 258). Bu durum kervansarayların çoğunun çatı kısmının kullanılmadığını gösterir. Merdiveni olan kervansaraylarda ise kalelere benzer özellikler göstermektedir.

\section{6. Kapı}

Kervansarayların kapıları en iyi demirden yapılmış güçlü, dayanıklı ve büyük ölçektedir (Turan, 1946: 477). Kervansaraylara tek bir kapıdan giriş çıkış yapılmaktadır. Bu kapı haricinde ön ve yan duvarlarda bulunan içten dişa şevlenen gözetleme veya 1şı alma amaçlı küçük pencereler bulunur. Kervansarayların giriş kapıları kırılma, yakılma kesilme veya delinme tehditlerine karşı kale kapıları gibi kaliteli demirden ve sağlam şekilde yapılmışlardır.

Yukarıda ele alınan altı maddeye bakıldığında Türkiye Selçukluları devri kervansaraylarının bütün unsurlarıyla tam bir kale hüviyeti taşımasalar da çok güçlü bir savunma ve korunmaya sahip oldukları görülmektedir. Ayrıca kervansarayların yapı özellikleri devletin yükselişine paralel olarak mükemmele yakın hale gelmiştir. Yükseliş devrinde özellikle Alâeddin Keykubad ve hatta sonrası dönemde en güzel kervansaray örnekleri verilmiştir. Nitekim Alaiye 
Kervansarayı ve Karatay Kervansaraylarının daha mükemmel ve güçlü surlarıyla daha korunaklı yapılar oldukları görülmektedir. Kervansaraylar büyük maliyetli yapılar olduğu için bu maliyeti karşılayabilecek güçteki kişilerin hükümdarlar ve hayırsever devlet adamları olduğu görülmektedir (Karatay Kervansarayını yaptıran Celaleddin Karatay hiç evlenmemiş ve malvarlığını hayır işlerine harcamıştır. Crane, 1975; Turan, 1948: 199-2000; Türkiye Selçuklu Devleti'ndeki sosyal kurumların teşekkülünde rol oynayan kişilerin siyasi ve ekonomik durumları konusunda ayrıntılı bilgi için bakınız: Bal, 2016)

\section{Sonuç}

Türkiye Selçuklu Devleti, Anadolu'da hüküm sürdüğü yaklaşık iki yüzyıl (1075-1308) boyunca ekonominin canlanması için gerekli ortam sağlanmaya çalışmıştır. Anadolu'da kuzeygüney, doğu-batı istikametinde ticaret yolları üstünde iki yüzü aşkın muhteşem büyüklükte ve güzellikte kervansaray yaparak korunma ve konaklama hizmeti verilmesini sağlamıştır.

Türkiye Selçukluları devri kervansaray yapıları Türk İslam devletlerinde kullanılan ribât geleneğinin devamı mahiyetindeki yapılardır. Ribâtlar öncelikle sınır karakolu mahiyetinde yapılmış ancak sonraları tekke, zaviye, medrese ve ticaret kervanlarına konaklama ve korunma amaçlı hizmet etmiştir. Türkiye Selçuklu dönemi kervansaraylarının da aynı şekilde çok amaçlı kullanımına şahit olmaktayız. Tabi bu durum devrin ihtiyaçlarına göre şekillenmiştir. Bu kervansarayların yapılış amacı önceleri tamamen ticaret kervanlarına korunma ve konaklama hizmeti vermekti. Ancak zamanın ve şartların değişmesi ile bu yapılar, iç ve dış mücadelelerde askeri üs, hükümdarların konaklama mekânı, sınır karakolu, savunma amaçlı kale ve hapishane olarak kullanılmıştır.

Türkiye Selçuklu kervansarayları; sur gibi kalın yüksek duvarları, mazgalları, payanda ve burçları, dendanlı yapıları, çatıya çıkan merdivenleri ve büyük kapıları ile kalelere benzemektedir. $\mathrm{Bu}$ abidevi eserlerin tam bir kale özelliği gösterdiği söylenemezse de kalın yüksek duvarları ile tam bir korunma yapısı olduğu kesindir. Kervansaraylar Türkiye Selçuklu Devleti’nin yükseliş devrinde daha mükemmel ve daha büyük hale getirilmiştir.

Türkiye Selçukluları devri kervansarayları Anadolu'nun mamur hale gelmesini ve Türkİslam mührünün bu topraklara vurulmasını sağlamışlardır. Bu yapıların korunması, aktif halde kullanılması ve kültürel bir zenginlik olarak gelecek nesillere tanıtılması büyük önem arz etmektedir.

\section{Kaynakça}

Aksarayî, K.M. (2000). Müsâmeret el-ahbâr ve müsâyeret el-ahyâr, Trk. trc. M. Öztürk, TTK; Haz. O. Turan, 1944, TTK.

Anonim, (1952). Anadolu Selçukluları Devleti Tarihi (Selçuknâme), Trk. trc. Feridun Nâfiz Uzluk, Örnek Matbaas1.

Aslanapa, O. (1991). Anadolu'da İlk Türk Mimarisi, Atatürk Kültür Merkezi Yayını.

Aslanapa, O. (1989). Türk Sanatı, Remzi Kitapevi.

Bal, M.S. (2004). II. İzzeddin Keykâvus Dönemi (1246-1262), Ankara Üniversitesi Sosyal Bilimler Enstitüsü, Doktora Tezi.

Bal, M.S. (1998). Türkiye Selçukluları'nda Ticari Hayat (1220-1277), Gazi Üniversitesi Sosyal Bilimler Enstitüsü, Yüksek Lisans Tezi. 
Bal, M.S. (2005). Moğol İstilâsından Sonra Türkiye Selçuklu Devleti İçinde Çıkan Türkmen (Oğuz) İsyanları (1243-1262). Kahramanmaraş Sütçü İmam Üniversitesi Sosyal Bilimler Enstitüsü Dergisi, 2 (2), 60-69.

Bal, M.S. (2016). Türkiye Selçuklu Devleti'ndeki Sosyal Kurumların Teşekkülünde Rol Oynayan Kişilerin Siyasi ve Ekonomik Durumları. TAD, 35 (59), 21-42.

Bal, M.S. (2005). Fotoğraf arşivi.

Bal, M.S. (2020). Fotoğraf arşivi.

Bakkal, A. (2019). Antalya Selçuklu Kervansarayları. Türk Akademik Araştırmalar Dergisi, 4 (4), 521-570. doi: 10.30622/ tarr.644055

Baş, A. (2007). Obruk Hanı. Anadolu Selçuklu Dönemi Kervansarayları, (Ed.) Hakkı Acun, 347359, Kültür ve Turizm Bakanlığı.

Crane, H.G. (1975). Material For the Study of Muslim Patronage in Seljuq Anatolia: The Life and Work of Jalâl Al-Dîn Qarâtâî, Harvard Üniversitesi, Doktora tezi.

Deniz, B. (2007). Ağzıkara Han. Anadolu Selçuklu Dönemi Kervansarayları, (Ed.) Hakkı Acun, s.321-347, Kültür ve Turizm Bakanlığı.

Denktaş, M. (2007). Karatay Hanı. Anadolu Selçuklu Dönemi Kervansarayları, (Ed.) Hakkı Acun, s.359-381, Kültür ve Turizm Bakanlığı.

Erdman, K. (1961). Das Anatolische Karavansaray des 13. Jahrhunderts, C. I-II, Verlag Gebr. Mann.

Erdman, K. (1961). Das Anatolische Kervansaray Des 13. Jahrhunderts, Katalog Abbildungen, Verlag Gebr. Mann.

Güler, M. (2019). Urfa'da Bilinmeyen Bir Yapı; Ağız Hanı. Turkish Studies, 14 (4), 2297-2331. DOI: 10.29228/TurkishStudies.23025

İbn Bibi. (1996). el-Evâmirü'l-Ala'iyye fi'l-Umuri'l-Ala'iye (Selçuk name), Trk. trc. Mürsel Öztürk, c. I-II, Kültür Bakanlığı Yayınları, Tıpkı Basım. 1956. el-Evâmirü'l- 'Alâ 'iyye fí'lumûri'l-Alâ'iyye, (Haz.) Adnan Sadık Erzi, Türk Tarih Kurumu Yayınları

Kadı Ahmed, N. el-Veled el-Şefik, Fatih ktp. 4519.

Köprülü, M.F. (1942). Ribat. Vakiflar Dergisi, II, s.267- 278.

Kuban, D. (2002). Selçuklu Çağında Anadolu Sanatı, YKY.

Önge, M. (2007). Zazadin Han. Anadolu Selçuklu Dönemi Kervansarayları, (Ed.) Hakkı Acun, Kültür ve Turizm Bakanlığı.

Özcan, K. 2015. Selçuklu Çağında Anadolu Kentleşme Koridoru. Bilig, Bahar, 173, 185-206.

Özergin, M.K. (1959). Anadolu Selçuklular Zamanında Yollar, İstanbul Üniversitesi Edebiyat Fakültesi Tarih Bölümü. Doktora Tezi.

Riefstahl, R. M. (1941). Cenubu Garbî Anadolu'da Türk Mimarisî Eserleri, Trk. trc. Cezmi Tahir Berktin, Kısım I, Maarif Matbaası.

Salt Araştırma arşivi, (Erişim tarihi: 01.08.2020), https://archives.saltresearch.org/handle/123456789/73215?mode=full,

Sönmez, Z. (1989). Anadolu Türk-İslâm Mimarisinde Sanatçılar, TTK.

T.C. Kültür ve Turizm Bakanlığı Niğde İl Müdürlüğü web. (2020). 
https://nigde.ktb.gov.tr/TR-74349/hanlar-bedestenler-ve-kervansaraylar.html

Tuncer, O.C. (2007). Anadolu Kervan Yolları, Vakıflar Genel Müdürlüğü Yayınları.

Turan, O. (1948). Celâleddin Karatay Vakıfları Ve Vakfiyeleri. Belleten, XII (45), 17-173.

Turan, O. (1946). Selçuklu Kervansarayları. Belleten, X (37-40), 471- 497.

Turan, O. (2013). Selçuklular Zamanında Türkiye, Ötüken Yayınları.

Yavuz, A.T. (1992). Anadolu Selçuklu Kervansaraylarında Mekân-İşlev İlişsisi İçinde Savunma ve Barınma. IX. Vakıf Haftası Bildirileri (Ankara, 2-4 Aralık 1991) 253-282.

Yiğit, İ. (2008). Ribât. DIA, 35, 76-79, (Erişim tarihi: 20.11.2015), http://www.islamansiklopedisi.info/.

\section{EKLER}

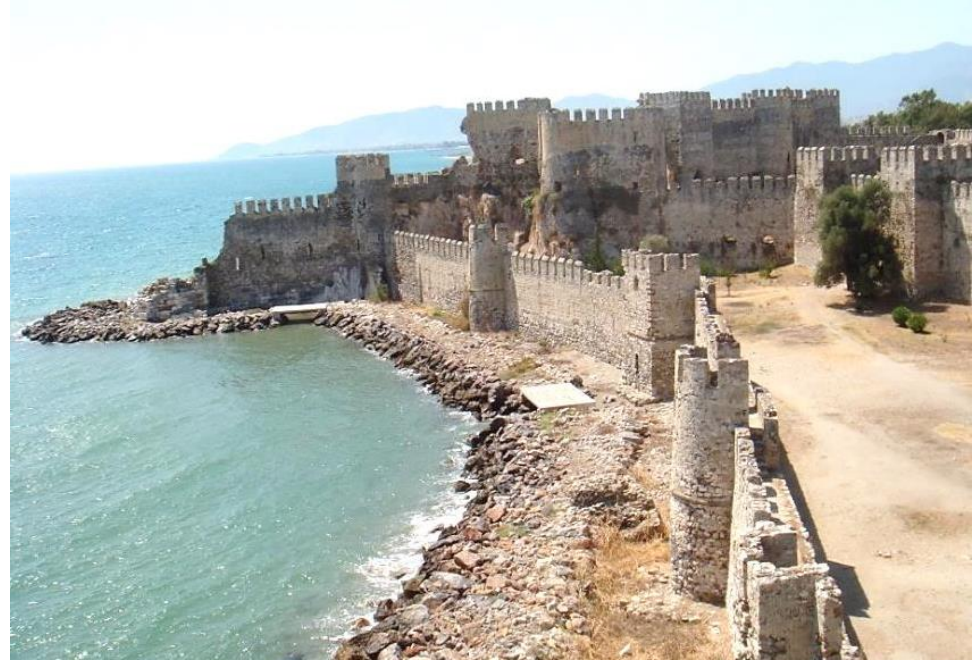

Fotoğraf 1: Anamur Mamure Kalesi, Tam bir kale formu örneği: siper olacak ve nişan alacak yüksek dendanlar, gözetleme yapılacak muhkem burç yapısı. (M. S. Bal Arşivi. 2010). 

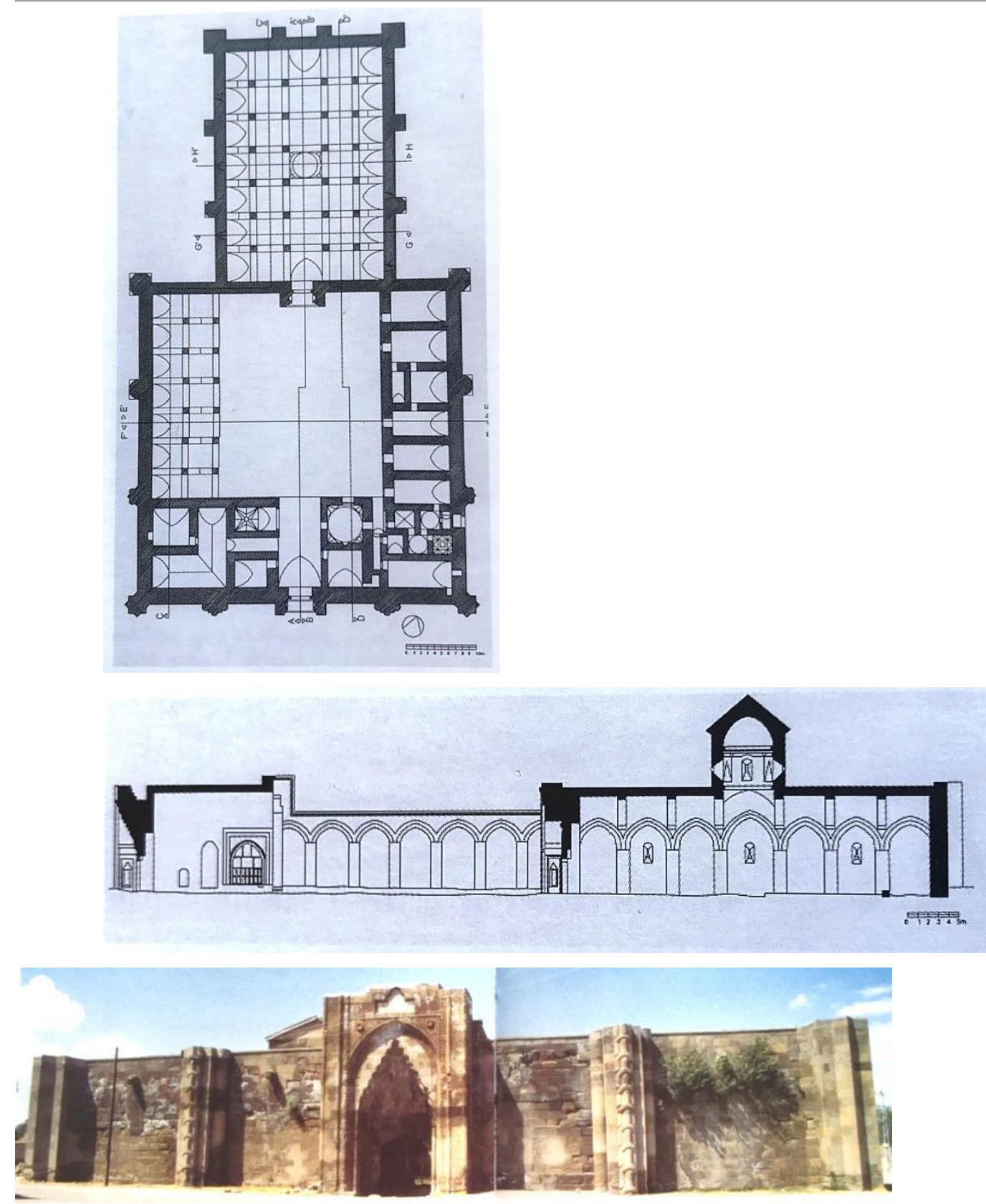

Fotoğraf 2: Karatay Hanı, plan ve ön cephe, (Kuban, 2002: 245).

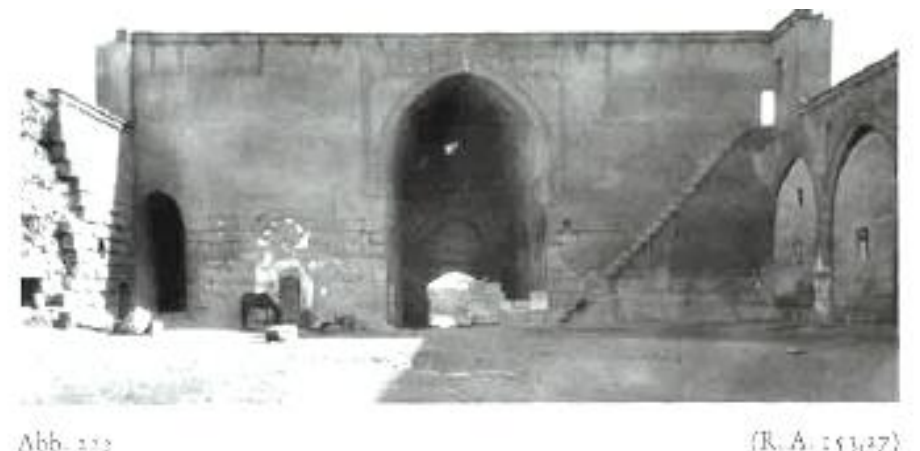

Fotoğraf 3: Karatay Hanı, Merdivenle çatıya çıkış, (Erdman, 1961: N: 32). 


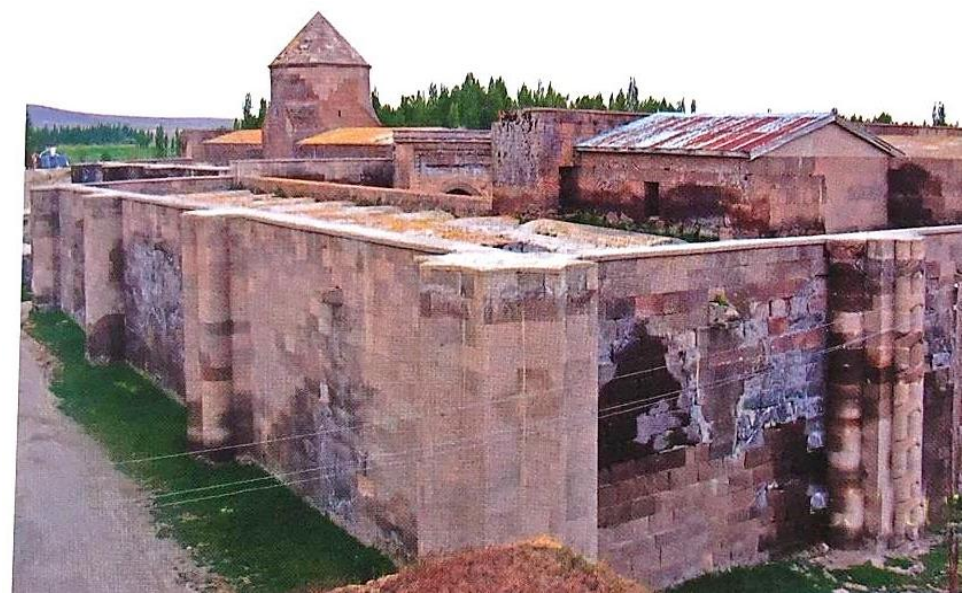

Fotoğraf 4: Karatay Hanı, üstten parapet yapının görünümü, (Denktaş, 2007: 363).

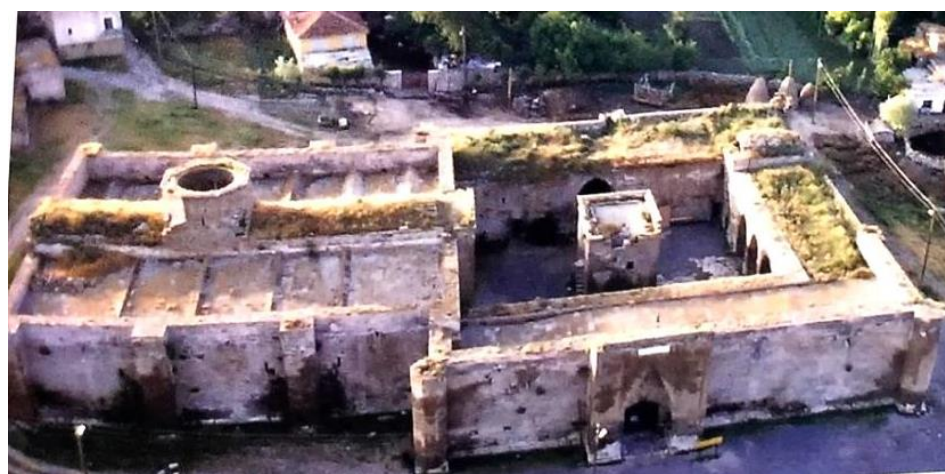

Fotoğraf 5: Ağzıkara Han. Üsten parapet yapının görünümü, (Deniz, 2007).

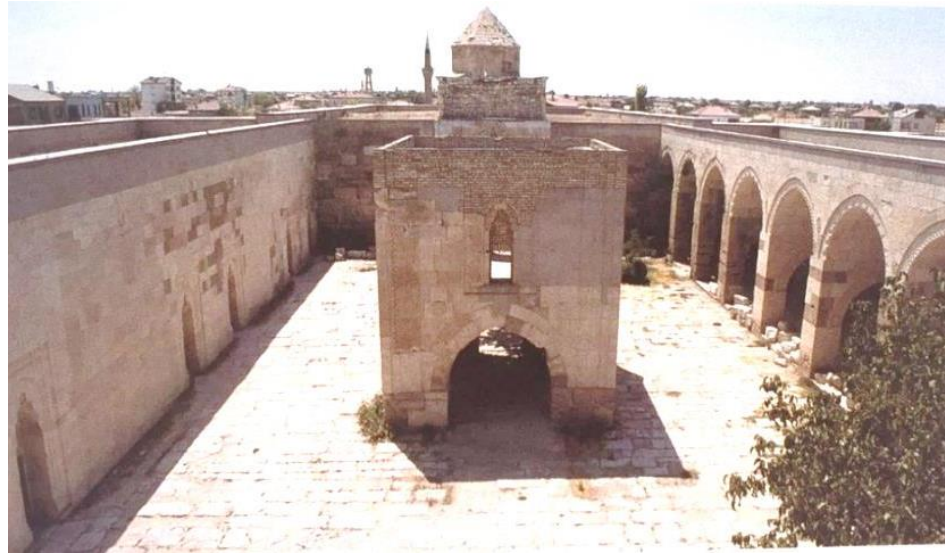

Fotoğraf 6: Çatı parapet yapı (Kuban, 2002:233) 


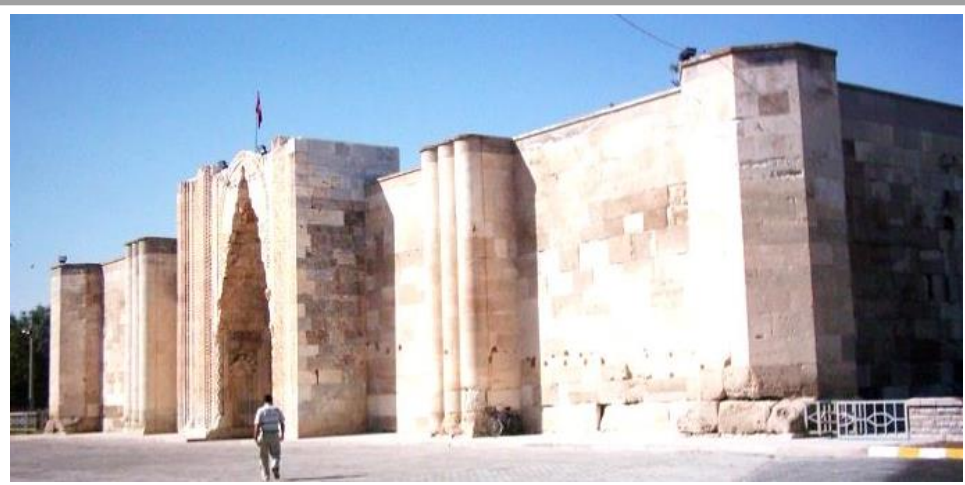

Fotoğraf 7: Aksaray Sultan Hanı, Kuzeyden ön cephe, (M. S. Bal Arşivi, 2005).
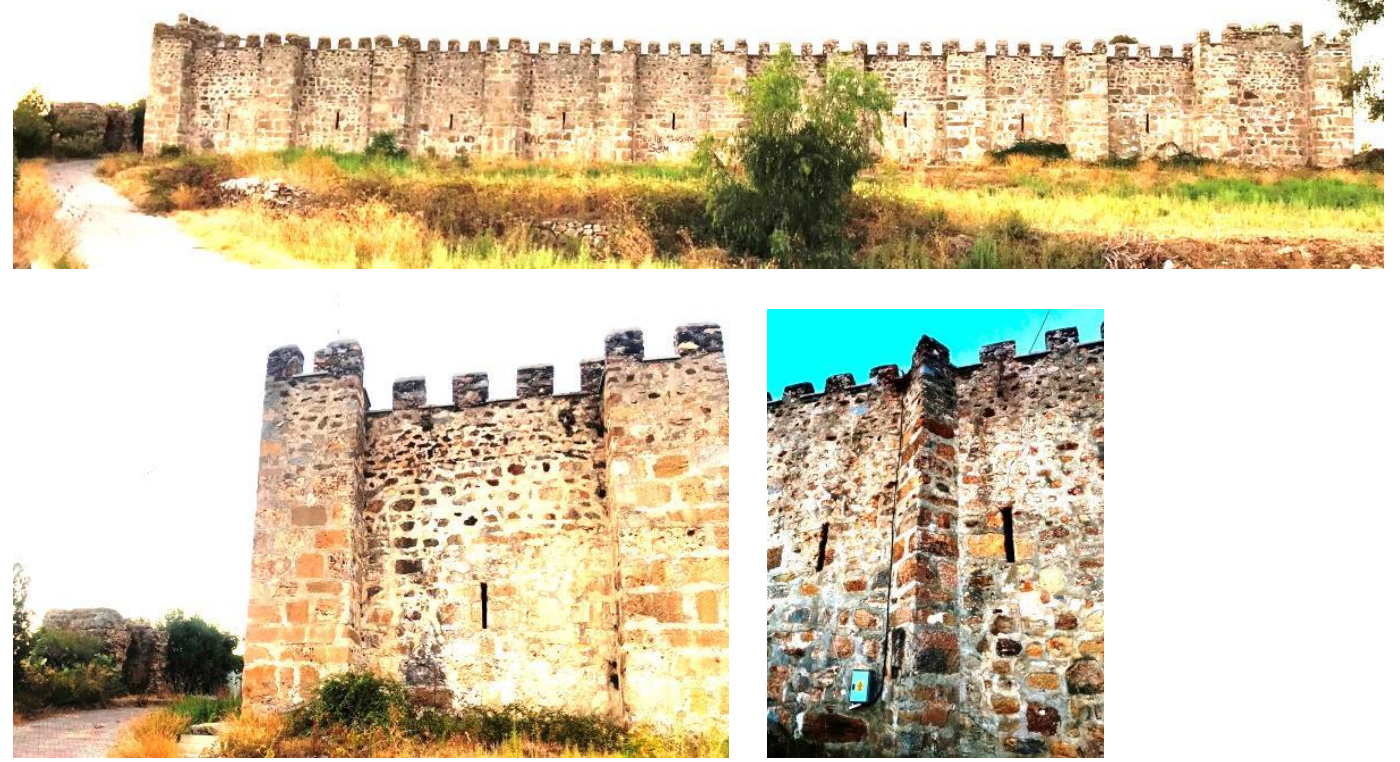

Fotoğraf 8: Şarabsa Han, Şarabsa Han'ın tepedeki heybetli görüntüsü, dendanlı yapısı, ve duvarlardaki mazgalları dikkat çekicidir. Ana yapının batısında küçük taş yapı görülmektedir (M.

S. Bal Arşivi, 2020). 


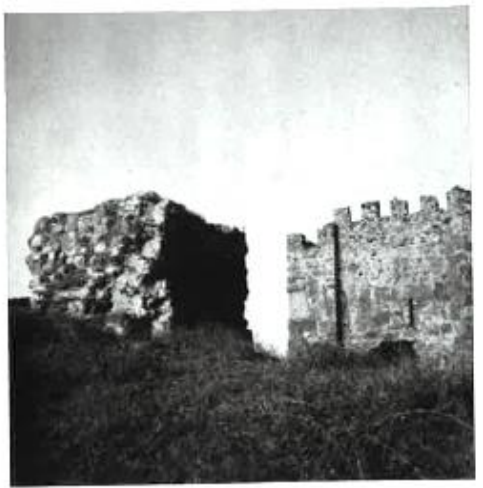

(E. A. for

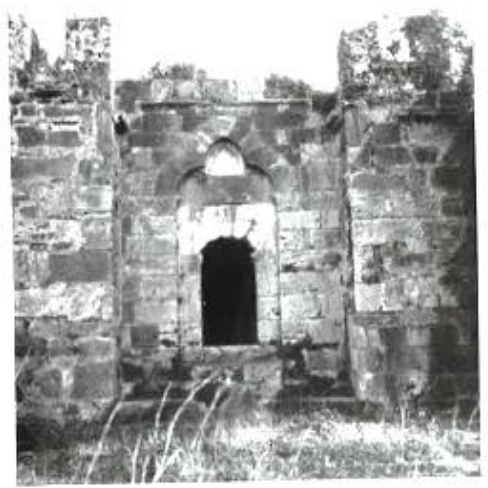

$\mathrm{Abi}, 3: 1$

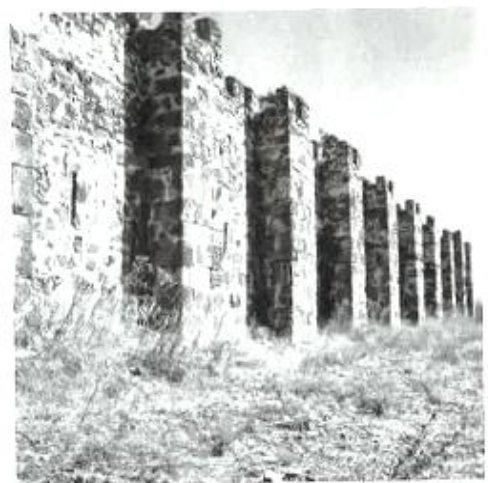

Ahi. 121

(E. $\wedge, 4010)$

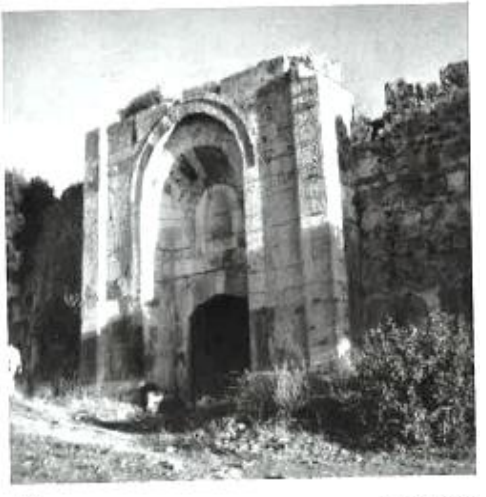

Ablo, 12

Fotoğraf 9: Şarabsa Han dendanlı yapısı, (Erdman, 1961: NO 53).

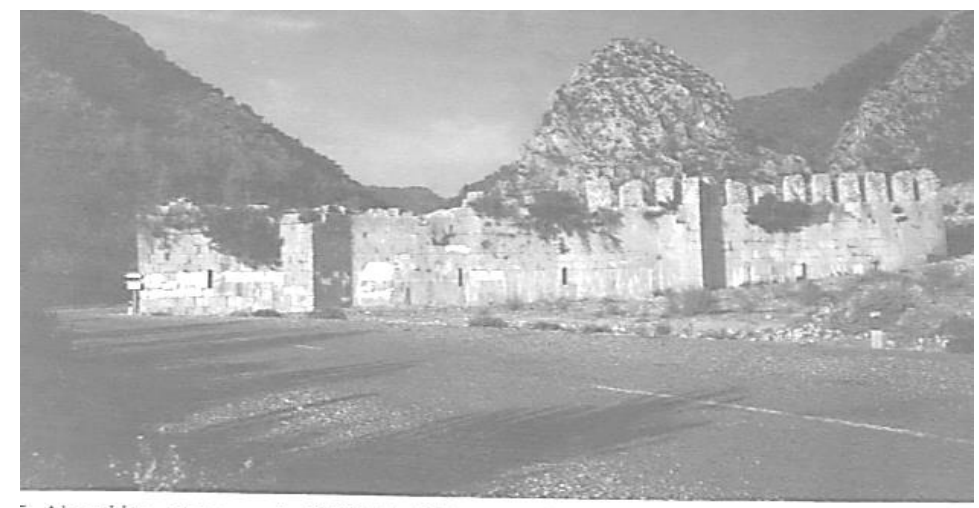

5. Alara Han, güney cephe, 1980 (A.T. Yauuz saydam arsini.

Fotoğraf 10: Alara Hanın dendanlı yapısı, (Yavuz, 1992:267). 

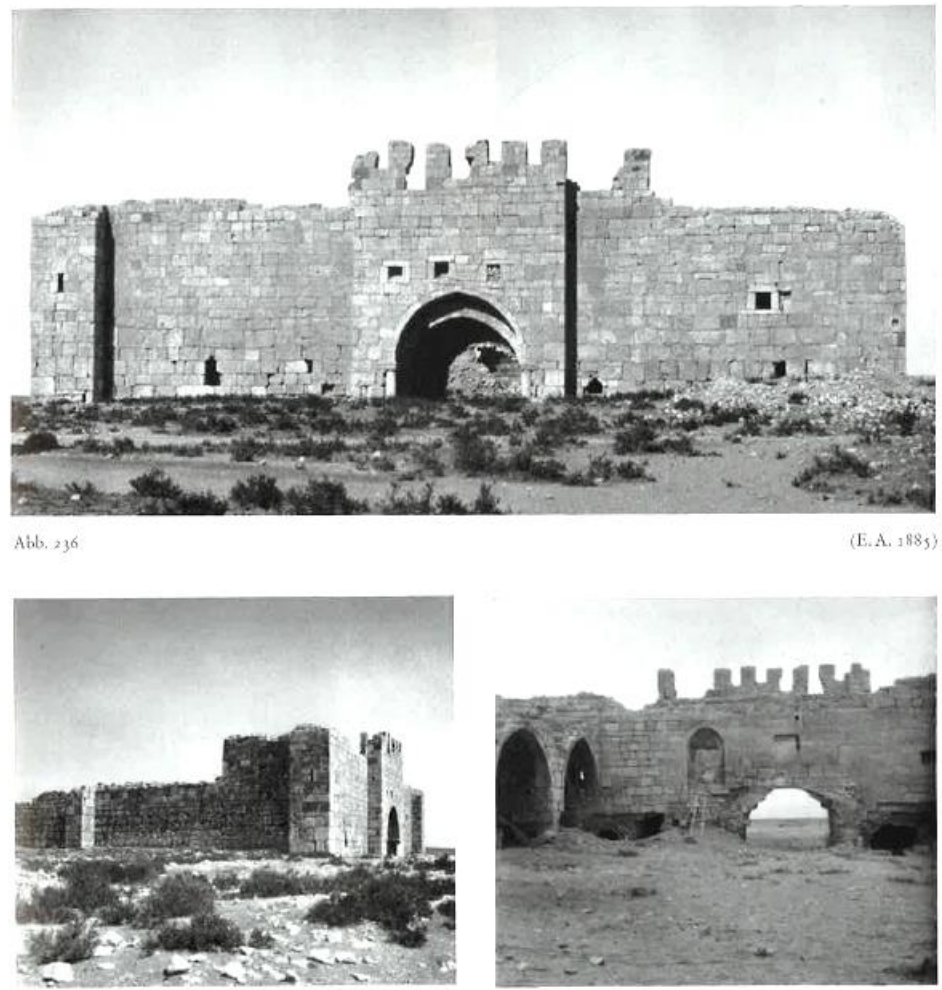

Fotoğraf 11: Obruk Hanın dendanlı yapısı. (Erdman, 1961: NO 34).

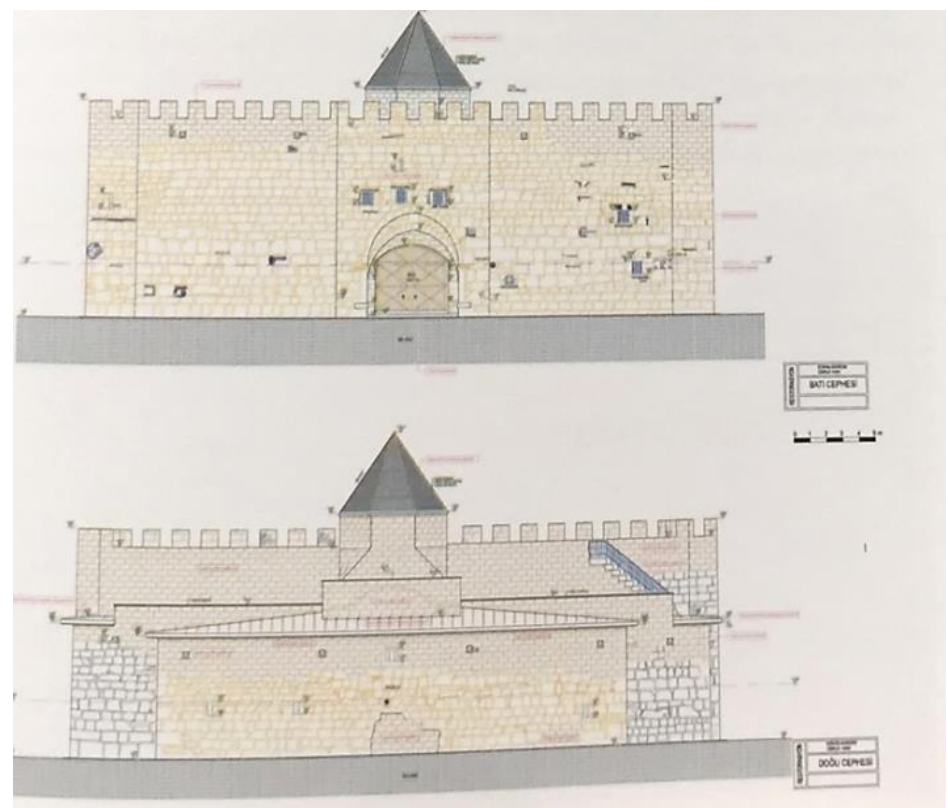

Fotoğraf 12: Obruk Han restorasyon planı, (Baş, 2007: 353). 


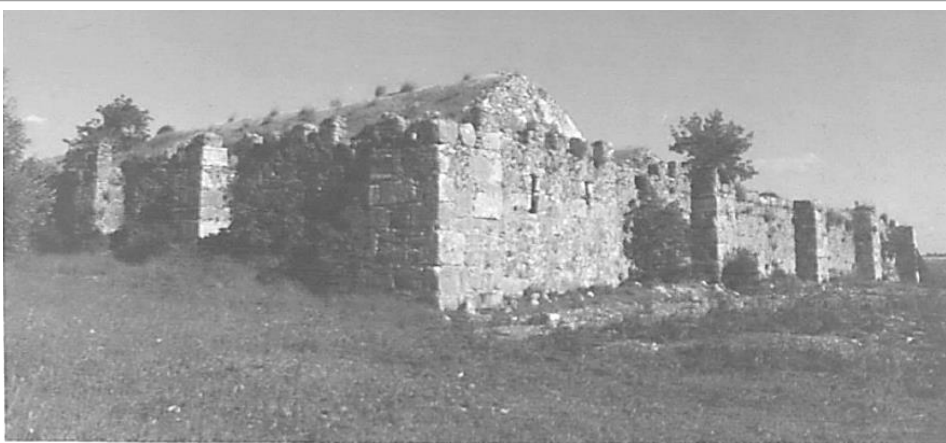

Fotoğraf 13: Kırkgöz Han, (Yavuz，1992:267).

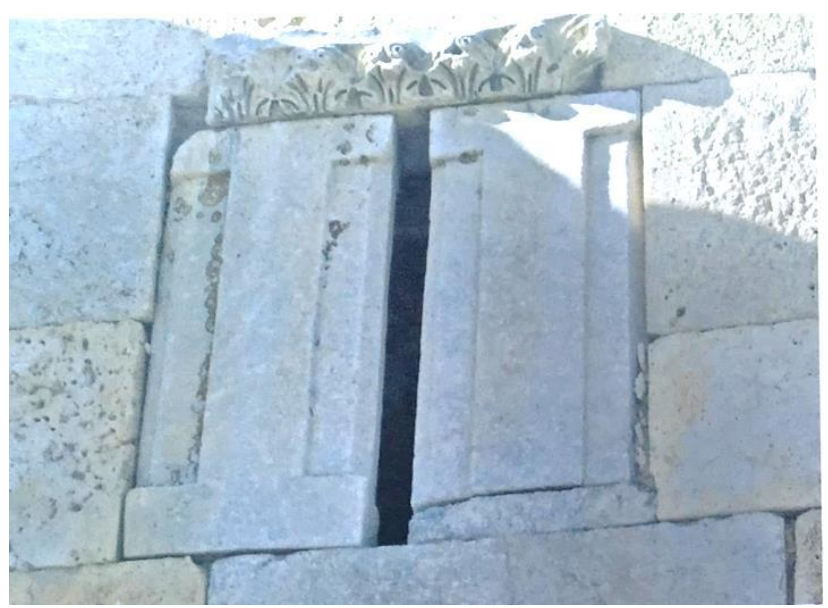

Fotoğraf 14: Mazgal (Önge, 2007: 205).

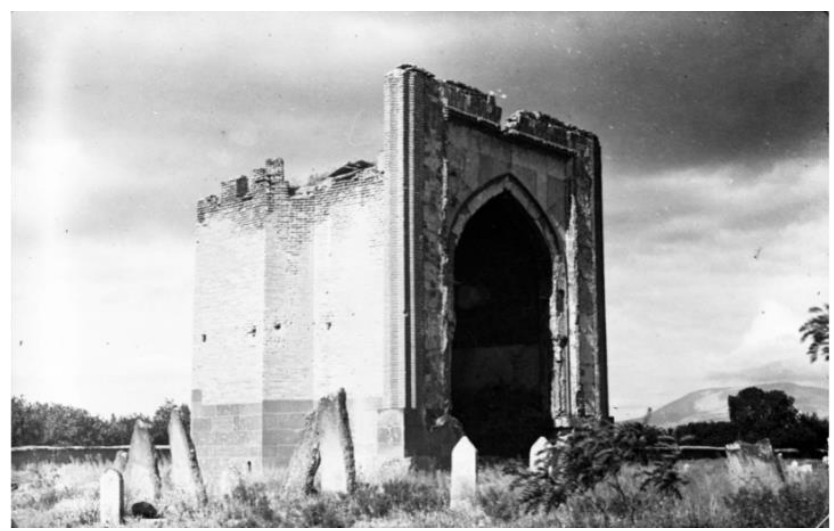

Fotoğraf 15: Gömeç Hatun türbesi motif amaçlı dendanlar (Salt, 2020). 


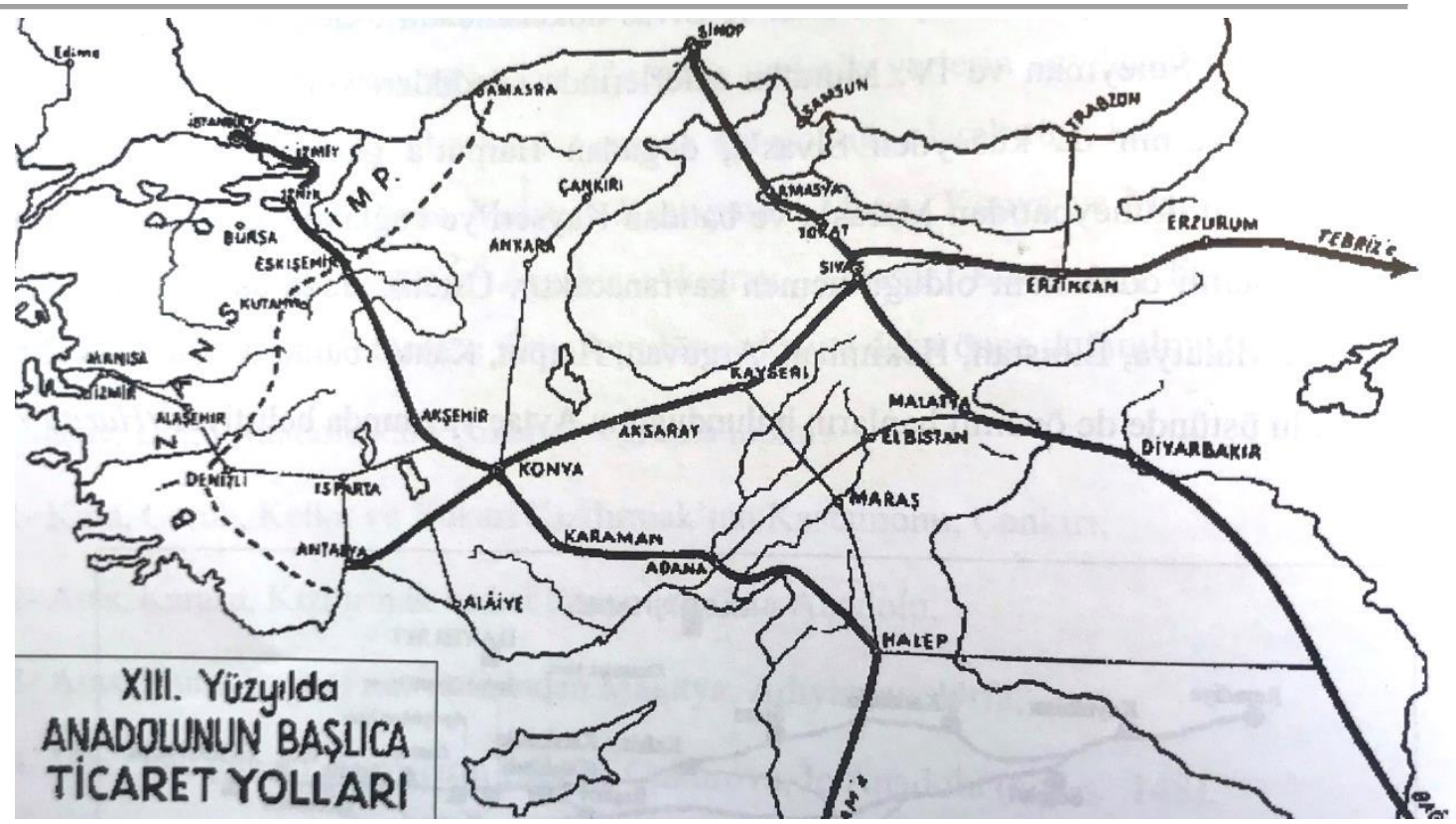

Harita 1: XIII. yy başlarında Anadolu'da ticaret yolları (Tuncer, 2007:28).

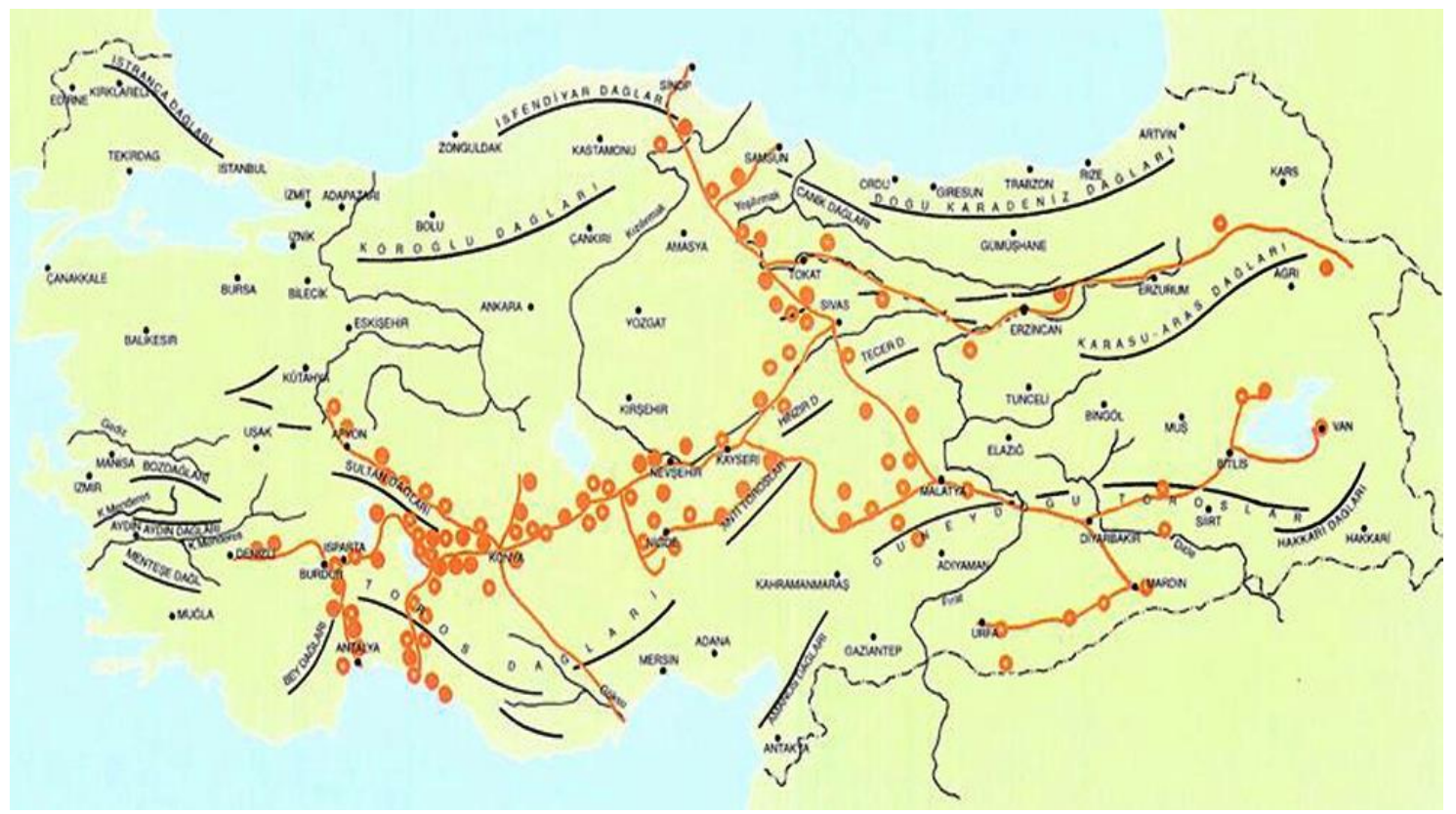

Harita 2: XIII. yy. Anadolu'da Kervansarayların yoğunluğu ve ticaret yolları (https://nigde.ktb.gov.tr/TR-74349/hanlar-bedestenler-ve-kervansaraylar.html). 